\title{
Treatment Study of Brook Water by Using the Ultrafiltration Pilot with Polymeric Membrane
}

\author{
LAURENTIU TATARU ${ }^{1}$, NARCIS BARSAN ${ }^{1 *}$ FLORIN MARIAN NEDEFF $^{1 *}$, ION SANDU ${ }^{2,3}$, EMILIAN MOSNEGUTU ${ }^{1}$, \\ DANA ALEXANDRA CHITIMUS ${ }^{1}$, ALINA COCHIORCA ${ }^{1}$, IOAN GABRIEL SANDU ${ }^{3,4 *}$ \\ ${ }^{1}$ Vasile Alecsandri University of Bacau, Department of Environmental Engineering and Mechanical Engineering, 157 Calea Marasesti Str., \\ 60011,5 Bacau, Romania \\ ${ }^{2}$ Alexandru Ioan Cuza University of Iasi, Arheoinvest Interdisciplinary Platform, Scientific Investigation Laboratory, 11 Carol I Blvd., 700506 \\ Iasi, Romania \\ ${ }^{3}$ Romanian Inventors Forum, 3 Sf. Petru Movila St., Bloc L11, III/3, 700089, Iasi, Romania \\ ${ }^{4}$ Gheorghe Asachi Technical University of Iasi, Materials Science and Engineering Faculty, 53A D. Mangeron Blvd., 700050, Iasi, Romania
}

This work presents an experiment aimed at determining the concentration of heavy metals found in the water resources of natural receivers. Heavy metals are very dangerous both for the aquatic life environment, influencing the health of the respective living beings and for the human health especially if there is an open contact between the human and the respective water source. Due to the different technological processes of the treatment plants, the wastewater, however, contains a high concentration of heavy metals, which means that those technological processes do not fully comply with the legal requirements. A good, viable solution that is being researched more and more at present is the use of types of polymeric membranes, suitably adapted in ultrafiltration processes of wastewater. Many of today's advanced researches focus on investigating the retention of heavy metals by membranes. The purpose of this work is to determine the concentration of the main heavy metals such as $\mathrm{Fe}^{2+}, \mathrm{Zn}^{2+}, \mathrm{Cu}^{2+}, \mathrm{Pb}^{2+}, \mathrm{Ni}^{2+}, \mathrm{Mn}^{2+}$, etc. and other elements such as: Fluorides, Nitrites $\mathrm{NO}_{2}-\mathrm{N}$, Phosphates $\mathrm{PO}_{4}-\mathrm{P}$, Ammonium $\mathrm{NH}_{4}-\mathrm{N}$ etc, both before using an organic membrane of PAN from hollow fibers and after cessation of the ultrafiltration experiment to determine the \% of the respective metals. can be removed after the ultrafiltration process. The results of the analyzes carried out during the experiment showed that some of the above mentioned chemical elements can be retained by more than $85 \%$ so that a membrane of PAN can reduce the degree of pollution of the waste water, especially where the waste water is directly discharged into natural source of water. At the same time, 14 chemical elements present in the waste water were analyzed and after determining the concentration of the heavy metals after the completion of the experiment it can be confirmed that the use of polymeric membranes is and will be a viable solution for the purpose of protecting the environment and health.

Keywords: heavy metals, PAN membrane, process parameters, ultrafiltration, wastewater

Industrial areas, regardless of the intensity of their activities, generate huge quantities of wastewater that contain pollutants from the most "friendly" with the environment to the most dangerous [1-11]. A quite important part of the industries generates waters that have in their composition high concentrations of heavy metals, such as: chromium, nickel, cadmium, manganese, iron, lead, etc., some being retained through the purification processes of the stations thus designed, others bypassing them, being a threat to aquatic life as well as to human health [12-28].

In addition to the conventional methods of purification, the membrane technology has several advantages because the membranes, regardless of their type, have lower costs, are easier to exploit, in addition, they offer the possibility to separate the compounds for future use [29-31].

The application of membranes in the processes of separation of heavy metals can have a rather high efficiency, but this efficiency depends very much on the working parameters of the experiment, such as the $\mathrm{pH}$ of the solution, the concentration of metals in the solution, the pressures that are created over time, other added solutions, operating time, etc. [32-34].

Some studies have shown a decrease in the rejection of heavy metals as the $\mathrm{pH}$ value decreases, which meant a decrease in the absorption of metal ions [35-41].

A similar study was demonstrated using a hollow fiber organic membrane, where significant cadmium removal was recorded [42-44].

Landaburu-Aguirre et al. [33] they showed in their study that membranes can retain copper and cadmium ions quite well varying different $\mathrm{pH}$ solutions, thus showing that $\mathrm{pH}$ is a key element in wastewater ultrafiltration processes.

The importance of removing heavy metals from wastewater has started to become a priority because they can cause quite serious human health problems, including: kidney disease, liver, lungs, nervous system etc [43, 45], even death [46].

The modern industry is developing quite rapidly and this leads to the generation of huge volumes of wastewater that possess concentrations of metals that are not biodegradable, compared to organic matter and this endangers the environment [46-48].

*email: narcis.barsan@ub.ro; florin_nedeff@ub.ro; gisandu@yahoo.com 
A variety of procedures have been performed: coagulation, flocculation, precipitation, etc. both in order to stabilize the compounds in water to be easier then removed by the ultrafiltration processes with membrane [2, 4, 6-12].

In the meantime, the membrane technology has improved, leading to improved ultrafiltration with polymers for the purpose of separating heavy metals, through the interaction between membrane polymers and the metals undergoing the ultrafiltration process [49-52].

These polymer-enhanced membranes have been tested and recommended where wastewater comes from battery manufacturing as well as from mining activities to treat and remove the respective metals [53-55].

Furthermore, the polymeric membranes have been tested to separate some of the radioactive chemical compounds such as Cesium, Strontium, Actinides etc. from the wastewater generated by the nuclear power plants which could subsequently be used or selected selectively [56-58].

The problem of organic or inorganic membranes remains the precipitation-induced fouling due to metals which then make the separation process more difficult, reducing both the ultrafiltration performance and the wear of the membrane module [59].

The hollow fibers of the membranes comprise a large surface but incorporated in a small volume and this is a great advantage because a large volume of the incoming water can be covered in the manner and need to operate at low transmembrane pressures [60].

Thus, several studies were carried out that aimed to eliminate the heavy metals from the wastewater, by experimenting the organic membranes of hollow fibers from different polymers including: PES, PEG, PAN, PBI etc. and the rejection factor was quite high, especially for $\mathrm{Cd}, \mathrm{Zn}$ and $\mathrm{Ni}$ ions [61].

The literature presented a study in which an organic membrane of hollow fiber PAN was able to absorb $\mathrm{Pb}$ and $\mathrm{Cu}$ ions very well, even though the permeate flux did not register a high value. However, the addition of nanoparticles in the solution subjected to ultrafiltration can give a high yield in the rejection of heavy metals [62].

In the present paper, it was proposed to test an organic membrane from PAN in the ultrafiltration process, using water from a natural source, respectively a river, to determine the variation of the concentration of heavy metals, respectively other chemical compounds, both before the end of the experiment and at the end.

First, the analysis of 14 chemical elements present in the collected water was performed by determining the concentration of each metal present in the water sample before starting the ultrafiltration process and then the concentration of the same metals at the specific time interval from the permeate samples was determined.

Finally, the analysis of the concentration of metals in the feed sample was repeated at the end of the process in order to determine the degree of membrane retention of said elements.

\section{Experimental part}

Materials and methods

The scheme of ultrafiltration process, containing an organic fiber membrane module, is presented in figure 1 .

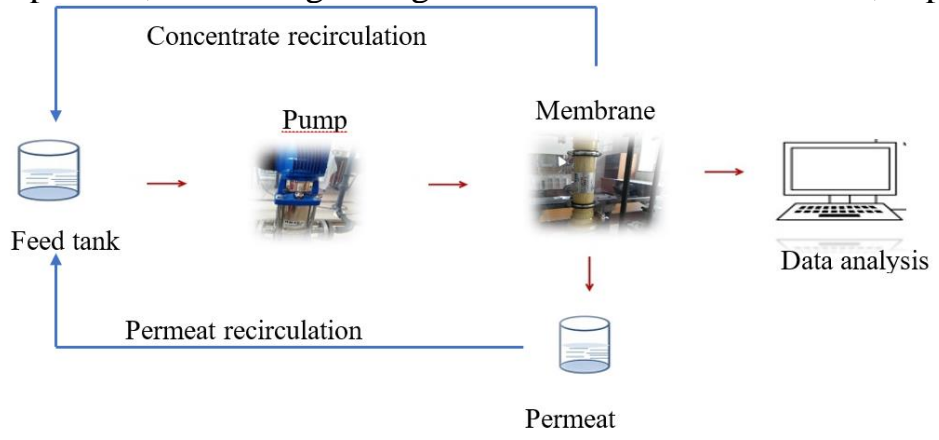

Fig. 1. Scheme of the installation work

As shown in Figure 1, the experimental installation consists of a membrane module provided with a protective housing, which incorporates an organic membrane of PAN, of hollow fibers, having a molecular weight of $13 \mathrm{kDa}$ fibers. Then the feed tank feeds the membrane with water from a natural source, respectively a river. The peristaltic pump has the role of draining the water from the supply tank, at an adjustable flow rate.

From the membrane level, the water containing different concentrations of heavy metals is divided in two ways: the permeate that is collected in the permeate reservoir, for analysis, being recirculated in the feed reservoir and the concentrate that is recirculated separately from the permeate, also in the reservoir power supply.

\section{Materials and substances}

The main element of the study was wastewater, containing heavy metals. It was collected from the Siret river, near the study enclosure, at the confluence between the Siret river and the water discharged from the Bacau wastewater treatment plant, according to figure 2 . 


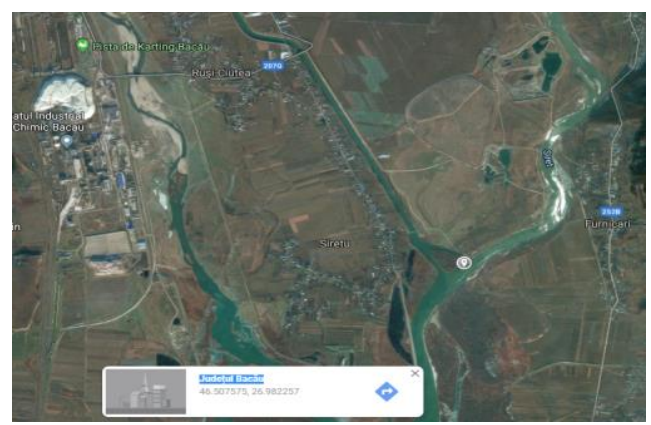

Fig. 2. The position of the sample water collection

It has been proposed as a study objective to investigate the water that has in its composition heavy metals because the water discharged from the treatment plants generally has different concentrations of $\mathrm{Pl}^{2+}, \mathrm{Zn}^{2+}, \mathrm{Fe}^{2+}, \mathrm{Cu}^{2+}, \mathrm{Mn}^{2+}$, $\mathrm{Co}^{2+}$, etc. and its discharge into the natural receiver, can have quite serious consequences for the environment, in case of improper management.

In this way it is proposed to test an organic membrane from PAN to see which metals are present in the collected water that can best be retained by the membrane chosen for the study.

In addition, a membrane with the size of the pores corresponding to the ultrafiltration domain was chosen and the water, before reaching the feed tank, passed through the pre-filtration stage through two filters, one of activated carbon and one of organic material, in order to protect the membrane from macromolecular impurities.

The membrane module was a constituent element of the MP 90 ultrafiltration pilot station in the Vasile Alecsandri University of Bacau research laboratory.

\section{Devices needed for the experiment}

In addition to the devices needed to determine the samples for analysis, the Spectrophotometer DR 3900 (Fig. 3a and $3 \mathrm{ab}$ ) was used to analyze the concentration of heavy metals in the samples during the ultrafiltration experiment.

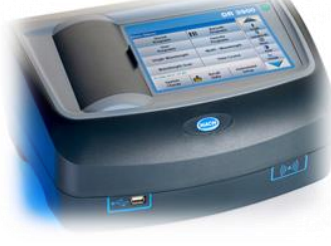

a

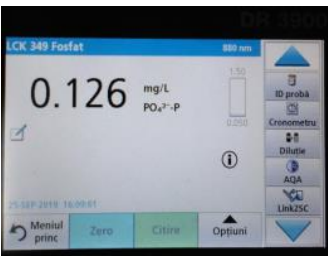

b

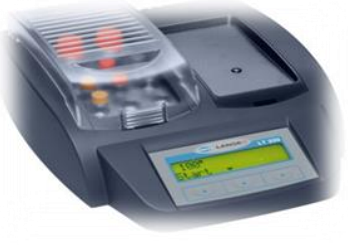

Fig. 3. The used equipements: a,b spectrophotometer DR 3900, c HACH LANGE LT200 activator

In addition, the HACH LANGE LT200 thermostat (Fig. 3c) was used, as some of the chemical elements required analysis at high temperature. All the equipment and devices in the study belong to the research laboratory of the University.

All the substances respectively the solutions necessary for the analysis of the samples collected during the experiment were purchased by Vasile Alecsandri University of Bacau.

\section{Working procedures}

The present study consisted of conducting an experiment with duration of 240 minutes, in which the operation of an installation provided with a membrane, regarding the retention of heavy metals in the water collected from a natural source, was followed.

First, the water underwent a pre-filtration, in order to retain the coarse particles that could have destroyed the membrane much faster. Then a sample was collected from the feed tank before the experiment began. The respective sample was analyzed properly, following the values of the indicators and then determining the concentration of the heavy metals with the help of appropriate equipment.

The duration of 240 minutes was enough to see the behavior of the ultrafiltration membrane. The parameters of the pilot installation were tracked over time, their data being recorded and further processed. After every 120 minutes, a permeate sample was collected to analyze the concentration of heavy metals after the membrane passage. As well as after the completion of the experiment, the collected permeate was subjected to analysis.

Finally, a sample of water was collected from the same feed tank, being less concentrated due to the accumulation on the surface of the membrane of the chemical or organic elements in the wastewater.

After the end of the experiment, all the equipment and equipment used in the research were cleaned and the recorded data were processed and validated. These data have confirmed, to an appropriate extent, the efficiency of an organic membrane from PAN in retaining different concentrations of heavy metals in the water proposed for the study. 
In the following chapters, the efficiency of retaining heavy metals from a natural water source and the influence of important parameters of a membrane filtration process were briefly presented.

\section{Results and discussions}

Determining the main parameters and indicators of the ultrafiltration process

The experiment that considered the retention of heavy metals in water from a natural source was carried out within a period of 240 minutes. The pilot system operated at a trans-membrane pressure of 1 bar, with no changes in system pressures during the entire working time of the process.

The flow rate of water entering the membrane initially registered $730 \mathrm{~L} / \mathrm{h}$, immediately following a downward variation due to the accumulation on the membrane of the metals, finally registering an input flow of $710 \mathrm{~L} / \mathrm{h}$ in just 240 minutes. This decline in flux leads to the fact that the membrane retains the metal particles on its surface and their accumulation speeds up the occurrence of membrane clogging, ultimately lowering the permeate productivity.

Due to the fact that in the analyzed water sample not only metals were found, the dissolved oxygen values remained somewhat constant, thus indicating that in the respective source of water there is a multitude of small particles that could not be removed through the membrane proposed for investigation.

Throughout the experiment, the temperature was evident to record increasing values by $3^{\circ} \mathrm{C}$ during the 240 working minutes. The concentration of metals present in water changed the $\mathrm{pH}$ value, registering an increase from 7.7 in the initial sample to 8.2 , being slightly basic.

\section{Analysis of the inflow water}

Before the water entered the membrane module, it was necessary to take a sample with a high content of metals, in order to determine to see the difference of the concentration before and during the ultrafiltration process, as a result of establishing the efficiency of the organic membrane of PAN. From the sample taken, 14 elements were determined by means of the DR 3900 Spectrophotometer and the results obtained were compared subsequently with those recorded from the permeate samples, respectively after water penetration through the membrane filtering surface.

Figure 4 shows the concentration for each of the 14 elements studied in the initial phase of the process, respectively concentration of heavy metals (Fig. 4a) and others chimicals elements (Fig. 4b), the water sample being completely homogenized by recirculation through the pump of the ultrafiltration pilot plant.

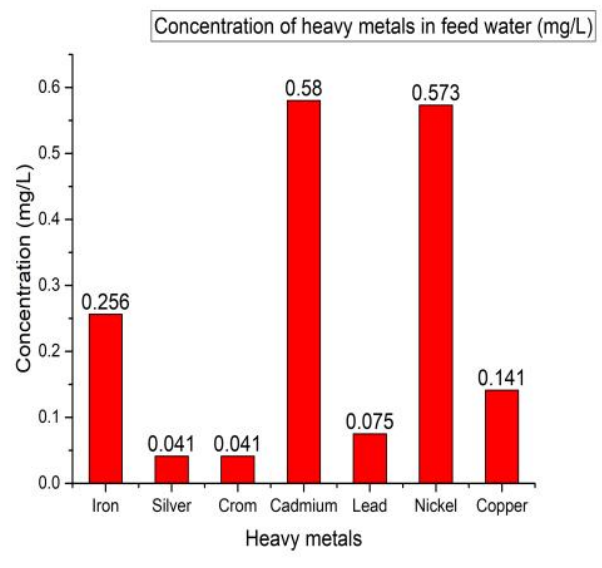

a

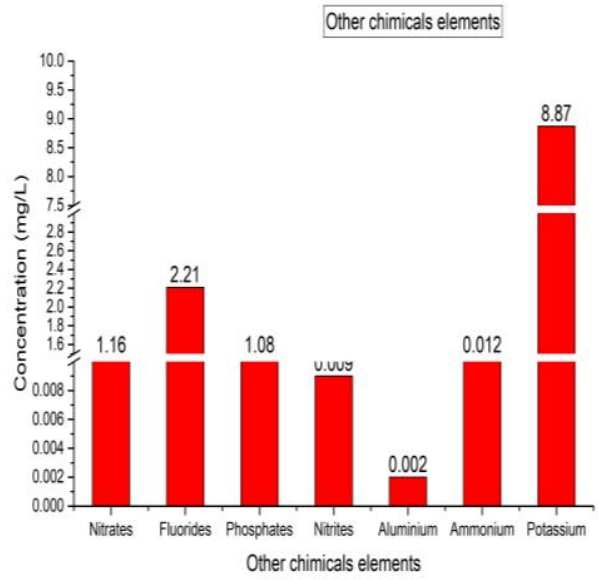

$\mathrm{b}$

Fig. 4. Analysis of the elements present in the wastewater, in the initial phase: a. heavy metals, b. other elements analyzed

The comparison of the sample data was strictly necessary because in this way it was possible to determine the concentration of heavy metals that could be retained on the membrane, thus determining the efficiency of the ultrafiltration process.

In the first instance it can be seen in figure $4 \mathrm{a}$, heavy metals such cadmium and nickel are predominant. The same can be said about fluorides and potassium. The presence in the wastewater of these elements means that the wastewater generated, treated and discharged upstream of the sampling site still has in its composition metal concentrations and other elements that cannot be removed to a great extent by the conventional wastewater treatment current procedures.

\section{Results obtained from the determination of permeate samples during the experiment}

As specified above, the experiment consisted of determining the concentration of the heavy metals from both the initial water sample and the permeate samples. Within two hours, the collected permeate was analyzed, tracking what percentage of each of the analyzed chemical elements were found in the permeate. 
Results obtained from the determination of permeate samples for heavy metals, during the experiment

In figure 5 concentration of iron and chrome from permeat samples is continuously decreased, which means that the organic membrane of PAN can more easily reject these metals.

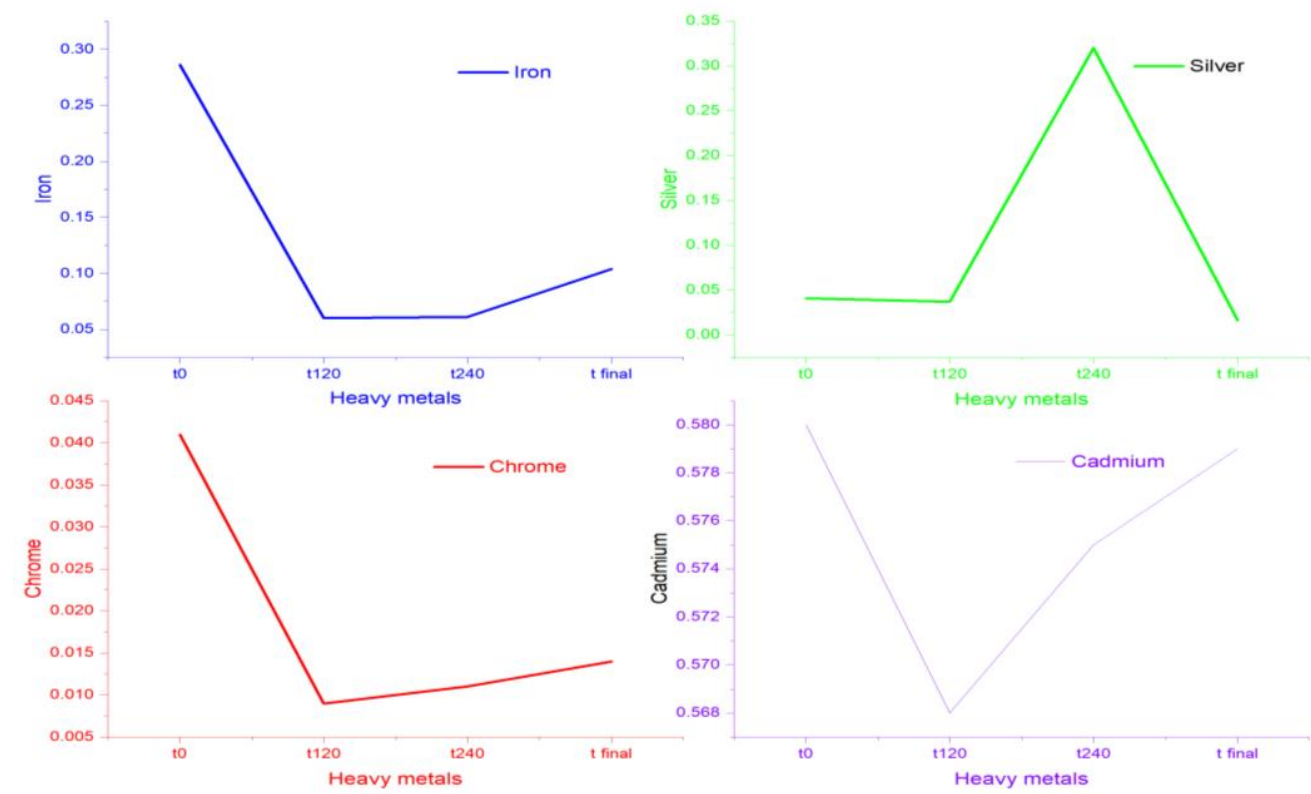

Fig. 5. Concentration of main heavy metals in permeate samples

As shown in figure 5, the silver decreases in concentration, in the permeate. This means that it accumulates on the membrane surface and at the same time increases the retention efficiency over time.

With the others words, in the analyzed permeate there is a rather high concentration of cadmium that means the membrane does not retain and does not satisfactorily reject the particles of this element, respectively the efficiency of the membrane in the PAN is quite low. The same cannot be said about chromium because the analyzed permeate showed a low concentration of this metal. The fact that the final sample shows the presence of low concentration of chromium, means that the membrane retains the chromium particles quite well.

In the permeate samples, the lead passed through the membrane almost entirely (Fig. 6), which means that the PAN membrane cannot retain this metal and its efficiency is very low. Due to the recirculation of the liquid, the solution composed of these metals was $100 \%$ homogeneous and this continuously entrained the particles of these metals.

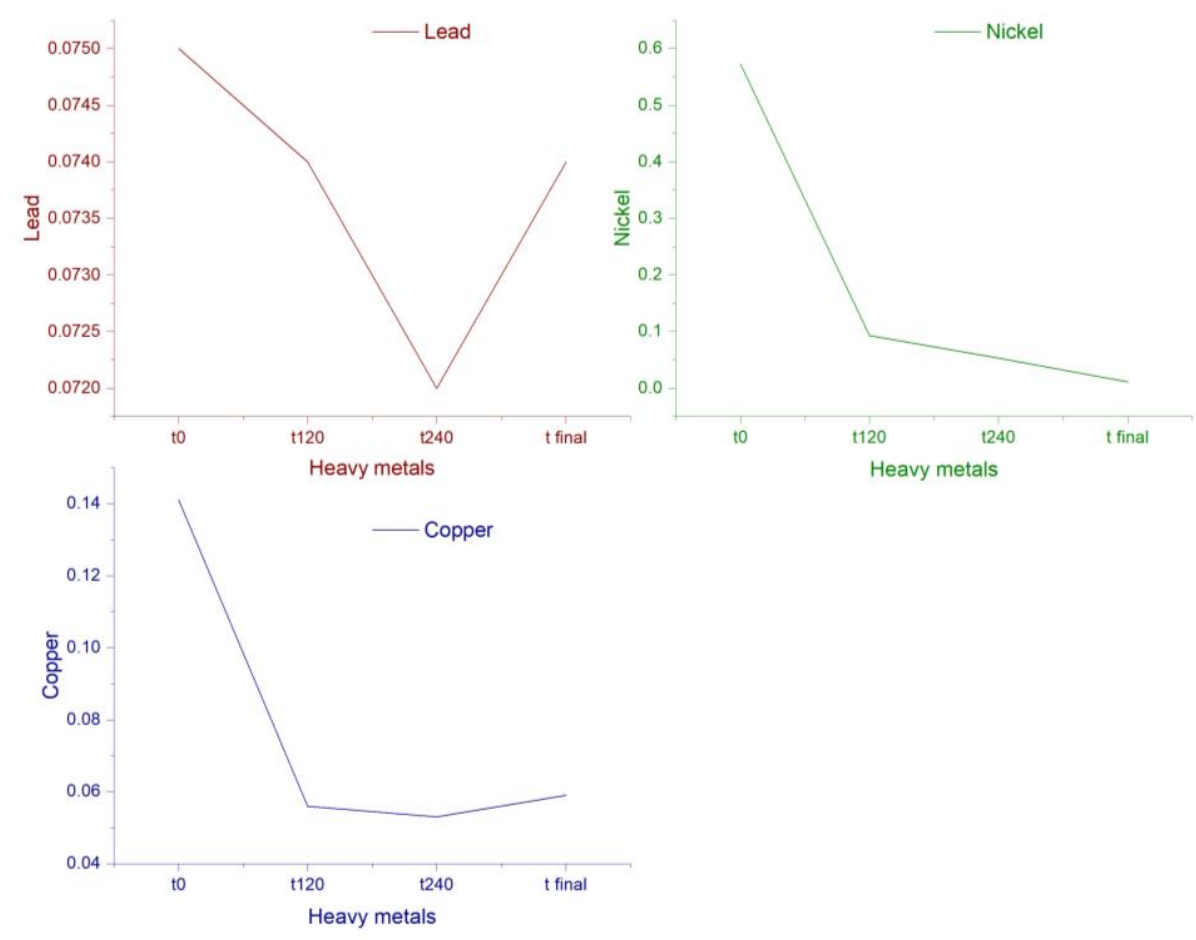

Fig. 6. Concentration of others heavy metals in permeate analyzed samples 
In figure 6, copper is found in the same situation as chromium. The copper was retained on the ultrafiltration membrane at a rather high concentration, and the calculation of its retention efficiency showing a fairly high percentage.

Figure 5 shows that iron was retained on the membrane at about $98 \%$, while lead recorded a retention rate of only 4\% (Fig. 6).

Following the analysis of the water samples with iron (Fig. 5) and lead content (Fig. 6), the wastewater sample before the experiment had a high concentration for both specified elements. The concentration of these two metals was different following the analysis by means of the spectrophotometer, especially in the case of the iron that was retained on the membrane in a concentration much higher than the lead.

Results obtained from the determination of permeate samples for others elements analyzed, during the experiment

The PAN membrane cannot retain nitrates in a satisfactory percentage because they have a retention rate of only 17\% (Fig. 7).

The use of an organic membrane from PAN is not sufficiently efficient where the waste water contains only nitrates, lead, fluorides, cadmium, etc.

Fluorides have shown that they can be retained or rejected by the PAN membrane only in a relatively small percentage (Fig. 7). This causes the efficiency of the ultrafiltration process for fluorine to decrease quite a bit and this membrane does not show efficiency.

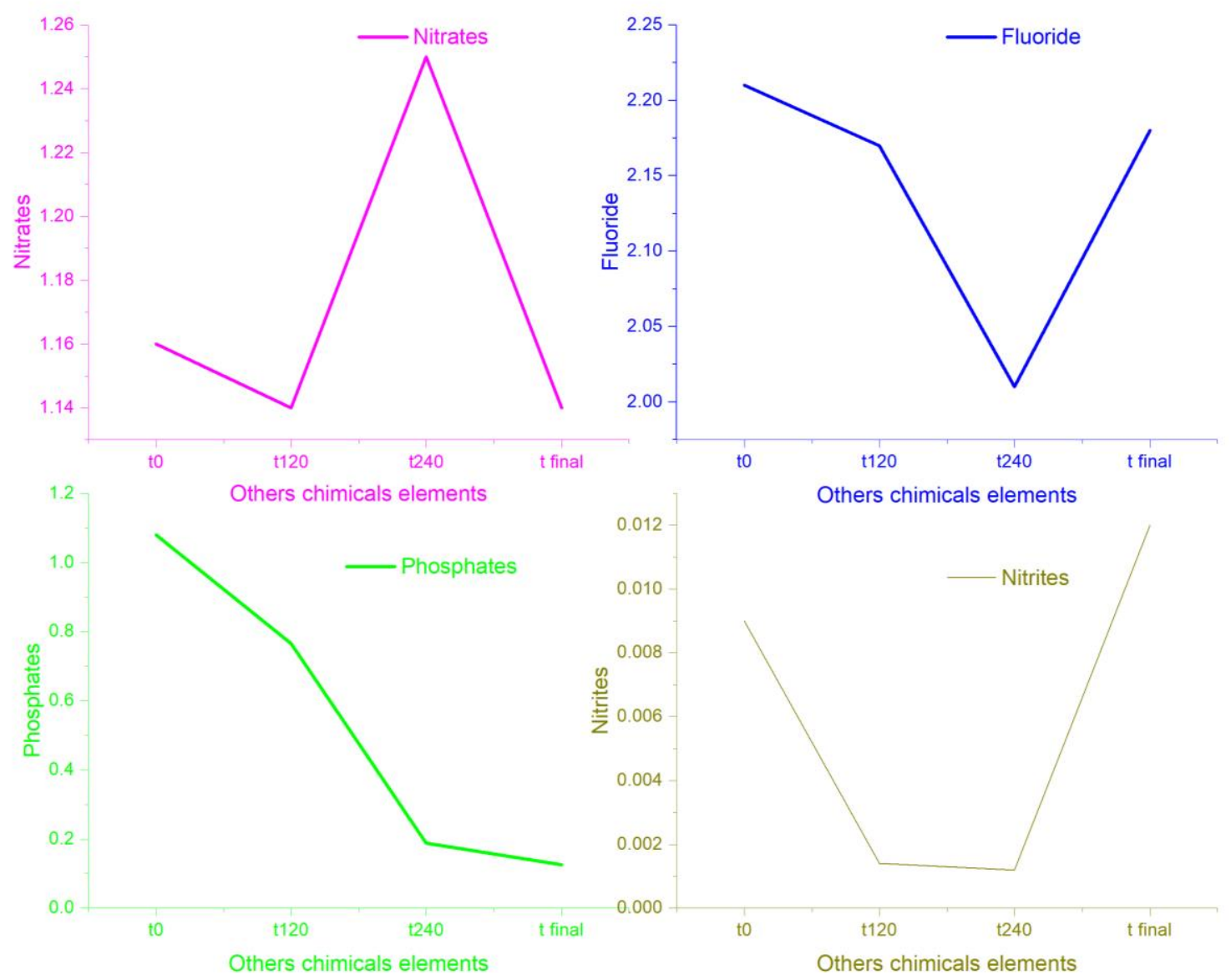

Fig. 7. Concentration of others elements in permeate analyzed samples

Compared to nitrates, the registered values of nitrites are different. Thus, the percentage of nitrite retention was $85 \%$ compared to only $17 \%$. In figure 7 , the phosphate accumulated on the membrane over time, leading to its fouling but during the experiment, its concentration in the permeate was decreasing, registering an increase in the permeate volume. However, the retention efficiency, after the calculations, showed a retention rate of about $83 \%$.

Following the analyzes regarding the determination of nitrates and phosphate from the wastewater samples it can be said that both elements can be successfully retained or rejected by an organic membrane from PAN.

From figure 8 it is observed that in both cases, aluminum and ammonia can be rejected by the PAN membrane. In the case of aluminum, in the end, its concentration tends to decrease compared to the concentration in the initial sample. This leads to the idea that the aluminum particles return to the feed tank due to the permeate and concentrate recirculation and the membrane has a greater rejection of this element. 


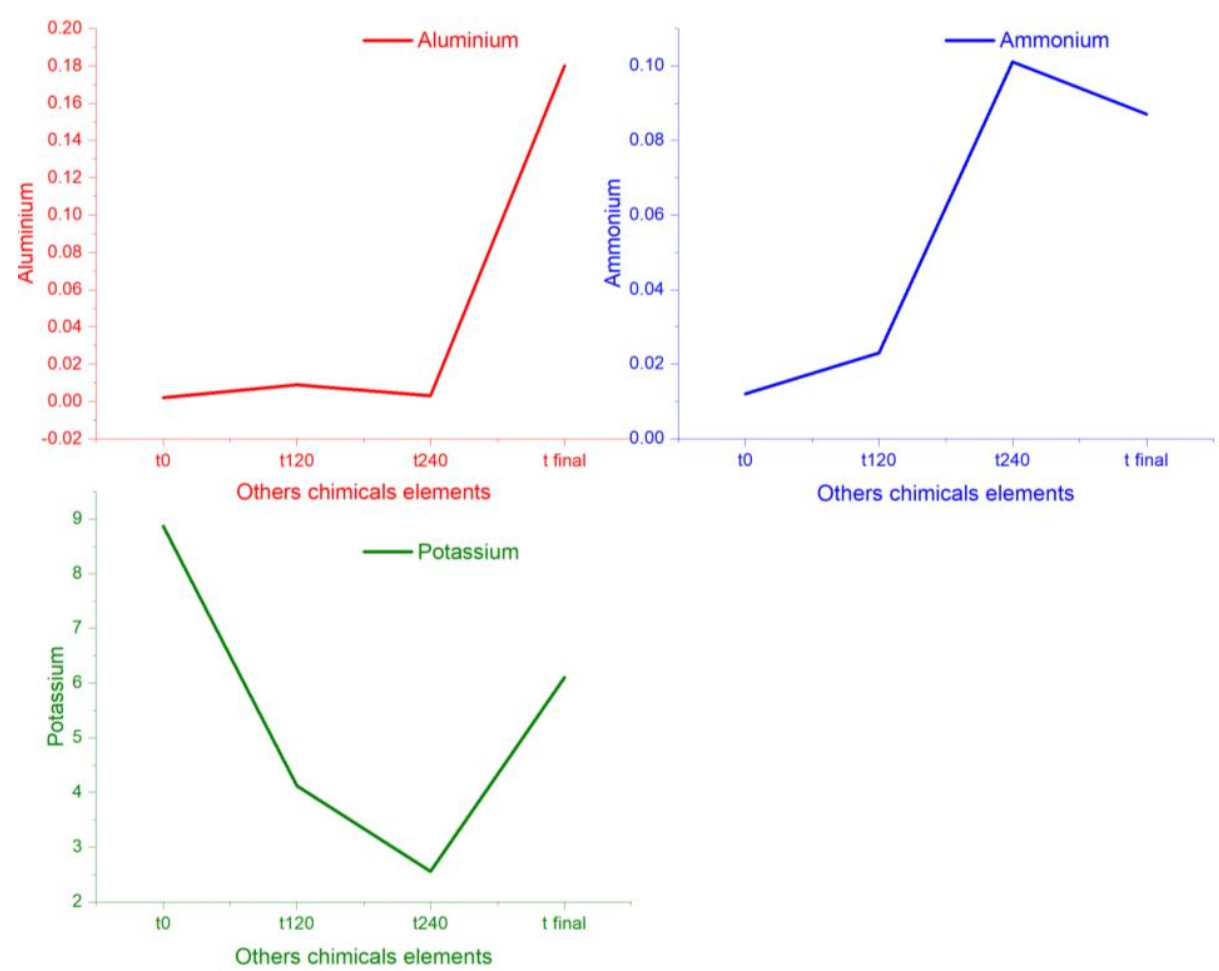

Fig. 8. Concentration of others elements in permeate analyzed samples

From figure 8 it can be concluded that the organic membranes of PAN can be used where the generated wastewater contains concentrations of copper, chromium, aluminum, ammonium, etc., because the percentage of retention of these elements is satisfactory.

In the case of ammonium, the membrane shows higher retention on the filtration surface, so that in the final sample, the ammonia concentration is lower than the permeate concentration, at the set sampling time. Is an advantage for ammonia, but the membrane tends to fouling up faster due to its accumulation on the pore walls.

The same was true for potassium. Potassium was found in the wastewater in high concentration due to the activities in the sampling area, which results in wastewater with high concentrations of potassium. The potassium removal efficiency reached $72 \%$.

In other words, the organic membrane of PAN from hollow fibers retained quite well potassium, which is one of the chemical elements best retained or rejected following the ultrafiltration process.

\section{Comparative analysis of the ultrafiltration membrane efficiency}

Figure 9 shows the retention efficiency, expressed as a percentage of the 14 chemical elements analyzed during the ultrafiltration process with an organic membrane of PAN, of bare fibers. The membrane has shown that some of the metals found in the waste water taken from a source and natural water can be fairly well rejected in the recirculating feed tank, preventing it from passing through it in order to affect the quality of the permeate.

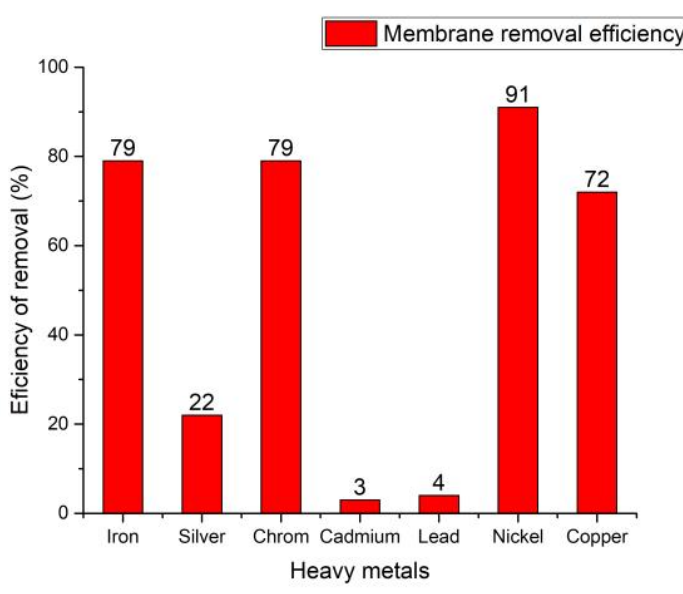

a

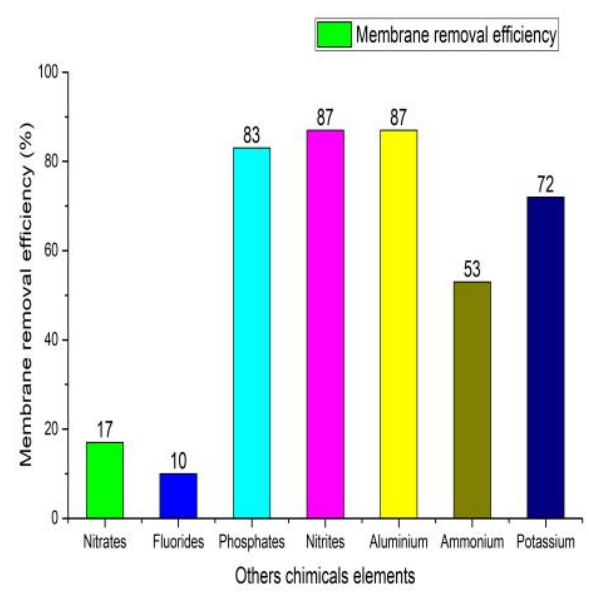

b

Fig. 9. The efficiency of organic membrane from PAN in retaining of: a. heavy metals, b. other elements 
Figure $9 \mathrm{a}$ and $\mathrm{b}$ shows the percentage of retention, respectively of rejection of the chemical elements that were analyzed during the experiment. As shown in the figure, for most of the 14 elements, the membrane recorded a retention rate of over 50\%, some of them adhering to the filtration surface, others being rejected in the water that was recirculated during the process.

As can be seen, most of the metals exceeded the value of $50 \%$, some reaching even 89 respectively $91 \%$. Nickel was the metal that was best retained and this means that the waste water resulting from industries such as machine and plant construction, metal structures etc. can be passed through a process based on the use of polymer membrane technology, respectively the PAN membranes.

Like nitrites, aluminum has reached a retention coefficient value of over $85 \%$, which means that the organic membrane of PAN can be used best for wastewater with high iron, chromium, phosphate, nitrite, aluminum, potassium content, nickel, copper, etc.

The elements mentioned above could be rejected more easily and the quality of the permeate was shown to be superior due to the presence of these elements in a rather low concentration.

Nitrites, silver, fluorine, cadmium and lead could not be retained on the membrane and their penetration through its pores was very visible.

\section{Conclusions}

The objective that was proposed in this paper regarding the retention of heavy metals in wastewater was achieved. Some of the metals and other chemical elements that are hazardous to humans and the environment could be retained on the membrane or rejected by the recirculation flow and this indicates that the polymeric membranes are quite advantageous as an ultrafiltration solution where wastewater is generated. containing heavy metals.

Compared to other chemical elements present in the waste water collected from a natural source, metals such as nickel, aluminum, chromium etc. have been the main element for which the organic fiber blank membrane of PAN has acquired advantages such as resistance in time, life cycle. prolonged during the ultrafiltration process, etc.

The present paper aimed to establish the membrane yield not only from the point of view of the retention percentage of the specified elements but also of the influence of parameters such as permeate volume, working time, time variation of the analyzed chemical parameters and indicators.

As shown in figure 9 the efficiency of the membrane in the retention of heavy metals was evident in the case of nickel, aluminum, nitrites, these, because of the superior properties of the membrane structure could only pass through it in very low concentrations, thus putting the imprint on the quality of the permeate.

Following the experiment presented in this paper it can be concluded that the polymeric membranes, especially those in PAN are a disadvantage where the waste water generated has in its composition nitrate, cadmium, lead, but this may retain many other elements besides those presented in this work, as specified in the literature.

Looking at the whole, it can be confirmed that polymeric membranes can be a viable and quite efficient solution in wastewater filtration, regardless of origin, and it can be said that in wastewater treatment plants where advanced wastewater treatment is required it can be replaced or added. a step through which the wastewater passes through membrane filters, offering not only the superior quality of the waste water in the natural receiver but also the reduction of heavy metal concentrations that cannot be eliminated by the classical treatment procedures.

\section{References}

1.BARSAN, N., JOITA, I., STANILA, M., RADU, C., DASCALU M., Environmental Engineering and Management Journal, 13, no. 7, 2014, p. 1561-1566.

2.BARSAN, N., NEDEFF, V., TEMEA, A., MOSNEGUTU, E., CHITIMUS A.D., TOMOZEI, C., Chemistry Journal of Moldova, 12, no. 1, 2017. p. 61-66.

3.FABIAN, F., NEDEFF, V., BIRSAN, N., MOSNEGUTU, E., Energy and Rev.Chim. (Bucharest), 70, no. 3, 2019, p. 881-886.

4.IRIMIA, O., TOMOZEI, C., PANAINTE, M., MOSNEGUTU, E.F., BARSAN, N., Environmental Engineering and Management Journal, 12, no. 1, 2013, p. 35-39.

5.MISAILA, L., NEDEFF, F. M., BARSAN, N., SANDU, I. G., GROSU, L., PATRICIU, O. I., GAVRILA, L., FINARU, A. L., Rev.Chim. (Bucharest), 70, no. 6, 2019, p. 2212-2217.

6.BARSAN, N., NEDEFF, V., MOŞNEGUȚU, E.F., PANAINTE, M., Environmental Engineering and Management Journal, 11, no. 12, 2012, p. 2131.

7.TURCU, M., BARSAN, N., MOSNEGUTU, E., DASCALU, M., CHITIMUS, D., RADU, C., Environmental Engineering and Management Journal, 15, no. 3, 2016, p. 521.

8.IRIMIA, O., TOMOZEI, C., PANAINTE, M., MOSNEGUTU, E., BARSAN, N., Environmental Engineering and Management Journal, 12, no. 1,2013 , p. 35.

9.IRIMIA, O., NEDEFF, V., PANAINTE, M., TOMOZEI, C., Journal of Engineering Studies and Research, 22, no. 1, 2016 , p. 64.

10.BARSAN, N., NEDEFF, V., TEMEA, A., MOSNEGUTU, E., CHITIMUS, A.D., TOMOZEI, C., Chemistry Journal of Moldova, 12, no. 1, 2017, p. 39.

11.BARSAN, N., JOITA, I., STANILA, M., RADU, C., DASCALU, M., Environmental Engineering and Management Journal, 13, no. 7, 2014, p. 1561.

12.IRIMIA, O., TOMOZEI, C., PANAINTE-LEHADUS, M., A mathematical model on the efficiency of the mechanical water filtering, 16th International Multidisciplinary Scientific Geo Conference SGEM 2016, Conference Proceedings, June 28 - July 6, 2016 , 2, p. 695.

13.TIRTOACA (IRIMIA), O., NEDEFF, V., PANAINTE-LEHADUS, M., TOMOZEI, C., Journal of Engineering Studies and Research, 22, no. 4, 2016, p. 61. 
14.BARSAN, N., NEDEFF, V., TEMEA, A., MOSNEGUTU, E., CHITIMUS, A.D., TOMOZEI, C., Chemistry Journal of Moldova, 12, no. 1, 2017, p. 61-66.

15.TATARU, L., NEDEFF, V., BARSAN, N., PANAINTE LEHADUS, M., CHITIMUS, D.A., The Annals of "Dunarea de Jos" University of Galati, Fascicle IX Metallurgy and Materials Science, 3, 2017, p. 39.

16.DASCALU, M.E., NEDEFF, F., MOSNEGUTU, E., SANDU, I.G., LOPEZ - RAMIREZ, J.A., Rev.Chim. (Bucharest), 70, no. 3, 2019, p. 866- 870.

17.TATARU, L., NEDEFF, V., BARSAN, N., MOSNEGUTU, E., PANAINTELEHADUS, M., SANDU, I., CHITIMUS, D., Mat. Plast., 55, no. 4, 2018, p. 660-685.

18.TATARU, L., NEDEFF, V., BARSAN, N., SANDU, A. V., MOSNEGUTU, E., PANAINTE-LEHADUS, M., SANDU, I., Mat. Plast., 56, no. 1, 2019, p. 97-102.

19.TATARU, L., NEDEFF, V., BARSAN, N., PANAINTE-LEHADUS, M., MOSNEGUTU, E., CHITIMUS, D., FABIAN, F., Journal of Engineering Studies and Research, 24, no. 2, 2018, p. 46.

20.TATARU, L., NEDEFF, V., BARSAN, N., PANAINTE-LEHADUS, M., MOSNEGUTU, E., CHITIMUS, D., Journal of Engineering Studies and Research, 22, no. 4, 2016, p. 42.

21.DASCALU, M.E., NEDEFF, F., CIUBOTARIU, V., LOPEZ-RAMIREZ, J.A., SANDU, I., Mat..Plast., 56, no. 2, 2019 , p. $426-428$.

22.FU, F.,WANG, Q., Journal of Environmental Management,92, 2011, p. 407-418.

23.HUANG ,J.H., ZENG, G.M., ZHOU, C.F., LI, X., SHI, L.J., HE, S.B., Journal of Hazards Materials, 183, 2010, p. $287-293$.

24.HUANG, J.H., PENG, L., ZENG, G.M., LI, X., ZHAO, Y., LIU, L.L., LI, F., CHAI, Q., Separation Purification Technology, 125, 2014, p. 8389.

25.CHEN, M., ZENG, G.M., ZENGZ, T., Science, 340, 2013, p. 674-676.

26.CHEN, M., ZENG, G.M., ZENG, Z.T., Nature, 499, 2013, p. 154.

27.XU, P., ZENG, G.M., HUANG, D.L., FENG, C.L., HU, S., ZHAO, M.H., LAI, C., WEI, Z., HUANG, C., XIE, G.X., LIU, Z.F., Science Total Environment, 424, 2012, p. 1-10.

28.TANG, W.W., ZENG, G.M., GONG, J.L., LIANG, J., XU, P., ZHANG, C., HUANG, B.B., Science Total Environment, 468-469, 2014, p. 1014-1027.

29.HASSAN, M., HANI, A.Q., Desalination, 164, 2004, p. 105-110.

30.VAN DER BRUGGEN, B., ESCOBAR, I.C., Modern applications in membrane science and tecnology, American Chemical Society, Washington, 2011.

31.ZHU, W.P., SUN, S.P., GAO, J., FU, F.J., CHUNG, T.S., Journal of Membranes Science, 456, 2014, p.117-127.

32.MUNGRAY, A.A., KULKARNI, S.V., MUNGRAY, A.K., Center Europe Journal Chemistry, 10, 2011, p.27-46.

33.LANDABURU AGUIRRE, J., PONGRÁCZ, E., KEISKI, R.L., Separation Purification Technology, 81, 2011, p. 41-48.

34.RAHMANIAN, B., PAKIZEH, M., MASKOOKI, A., Journal of Hazards Materials, 184, 2010, p.261-267.

35.JUANG, R.S., XU, Y.Y., CHEN, C.L., Journal of Membrane Science, 218, 2003, p.257-267.

36.XU, K., ZENG, G.M., HUANG, J.H., WU, J.Y., FANG, Y.Y., HUANG, G., LI, J., XI, B., LIU, H., Colloidal Surface A, 294, 2007, p. 140146.

37.BOCIORT, D., GHERASIMESCU, C., BERARIU, R., BUTNARU, R., BRANZILA, M., SANDU, I., Rev. Chim. (Bucharest), 63, no. 11, 2012, p. 1152 .

38.SANDU, A.V., VASILACHE., V., SANDU, I.G., SIELIECHI, J.M., KOUAME, I.K., MATASARU, P.D., SANDU, I., Materials, 12, no. 23, 2019, article no. 3836 .

39.OlTEANU, M., BARAitARU, A., PANAIT, A.-M., DUMITRU, D., BOBOC, M., DEAK, G., Water Air Soil Pollut., 230, 2019 , p. 179.

40.TOCIU, C., DEAK, G., MARIA, C., IVANOV, A.A., CIOBOTARU, I.E., MARCU, E., MARINESCU, F., CIMPOERU, C., SAVIN, I., CONSTANDACHE, A.C., IOP Conf. Ser. Mater. Sci. Eng. 572, 2019, article no. 012109.

41.BESNEA, D., GHEORGHE, G.I., DONTU, O., MORARU, E., CONSTANTIN, V., MOGA, I.C., Int. J. Mechatron. Appl. Mech., 4, 2018, p. 61.

42.ZENG, G.M., LI, X., HUANG, J.H., ZHANG, C., ZHOU, C.F., NIU, J., SHI, L.J., HE, S.B., LI, F., Journal Hazards Materials, 185, 2011, p. 1304-1310.

43.BOCIORT, D., GHERASIMESCU, C., BERARIU, R., BUTNARU, R., BRANZILA, M., SANDU, I., Rev. Chim. (Bucharest), 63, no. 12, 2012, p. 1243 .

44.FU, F., WANG, Q., Journal of Environment Management, 92, 2011, p. 407-418.

45.MONIER, M., ABDEL-LATIF, D.A., Journal of Hazards Materials, 250-251, 2013, p. 122-130.

46.BESSBOUSSEA, H., VERCHËREA, J.F., LEBRUNA, L., Chemical Engineering Journal, 187, 2012, p. 16-28.

47PAPADATU, C.P., BORDEI, M., ROMANESCU, G., SANDU, I., Rev. Chim. (Bucharest), 67, 2016, p. 1728.

48.OZAY, O., EKICI, S., BARAN, Y., AKTAS, N., SAHINER, N., Water Resources, 43, 2009, p. 4403-4411.

49.BOLTO, B.A., Science, 20, 1995, p. 987-1041.

50.BOLTO, B., GREGORY, J., Water Resources, 41, 2007, p. 2301-2324.

51.GECKELER, K., LANGE, G., EBERHARDT, H., BAYER, E., Pure Application Chemistry, 52, 1980, p. 1883-1905.

52.GECKELER, K.E., VOLCHEK, K., Environment Science Technology, 30, 1996, p. 725-734.

53.ARAR, O., KABAY, N., SANCHEZ, J., RIVAS, B.L., BRYJAK, M., PENA, C., Environment Program Sustainable Energy, 33, 2014, p. 918924.

54.BEOLCHINI, F., PAGNANELLI, F., MICHELIS, I.D., VEGLIO, F., Environment Science Technology, 40, 2006, p. $2746-2752$.

55.HUANG, Y., DU, J.R., ZHANG, Y., LAWLESS, D., FENG, X., Separation Purification Technology, 154, 2015, p. 1-10.

56.NOVIKOV, A.P., SHKINEV, V.M., SPIVAKOV, B.Y., MYASOEDOV, B.F., GECKELER, K.E., BAYER, E., Radiochimical Acta, 46, 1989, p. $34-45$.

57.NORTON, M.V., DI, F.A., HALLEN, R.T., Water Environment Resources, 69, 1997, p. 244-253.

58..NAVARRO, R.R., WADA, S., TATSUMI, K., Journal of Hazards Materials, 123, 2005, p. 203-209.

59.JELLINEK, H.H.G., LUH, M.D., Journal of Polymeric Science A, 1, no. 7, 1969, p. 2445-2449.

60.ZHU, W.P., GAO, J., SUN, S.P., ZHANG, S., CHUNG, T.S., Journal of Membrane Science, 487, 2015, p. 117-126.

61.ZHU, W.P., SUN, S.P., GAO, J., FU, F.J., CHUNG, T.S., Journal of Membrane Science, 456, 2014, p. 117-127.

62.KUMAR, M., SHEVATE, R., HILKE, R., PEINEMANN, K.V., Chemical Engineering Journal, 301, 2016, p.306-314.

Manuscript received: 25.11.2019 